\title{
THE GENETICS OF PLUMAGE PHASE DIMORPHISM OF THE SOUTHERN GIANT PETREL MACRONECTES GIGANTEUS
}

\author{
P. D. SHAUGHNESSY \\ Genetics Department, University of Adelaide, South Australia, and \\ Antarctic Division, Department of Supply, Commonwealth of Australia
}

Received 1.xii.69

\section{InTRODUGTION}

THERE are two species of giant petrel. The southern one, Macronectes giganteus (Gmelin) breeds in Subantarctic and Antarctic regions, while the northern one, $M$. halli Mathews, breeds only on islands north of the Antarctic Convergence (Carrick and Ingham, 1967). Both species breed on Macquarie Island (latitude $54^{\circ} \mathrm{S}$, longitude $159^{\circ} \mathrm{E}$ ), where the present study was undertaken. Warham (1962) has described the biology of both species at Macquarie Island.

It is $M$. giganteus that shows the marked plumage phase variation. This has been well documented by early authors of Antarctic and Subantarctic fauna (e.g. Wilson, 1907; Murphy, 1936; Falla, 1937). There is a white phase, in which the birds are completely white, except for a few black feathers scattered at random through the plumage, and a dark phase in which the plumage varies from uniformly dark blackish-brown through dark brown to grey-brown with greyish-white on the head, neck and upper breast. Murphy (1936), Falla (1937) and Warham (1962) considered that the head and neck of dark birds become lighter as the bird ages.

Down colour of chicks has been described by Murphy (1936). The protoptyle down of dark phase chicks is white except on the chicks back, neck and head, where it is grey. This is replaced by the grey mesoptyle down. The down of white phase chicks is white at both stages.

Inheritance of the plumage phases of $M$. giganteus has not previously been studied in any detail. From observations at the South Orkney Islands, Ardley (1936) claimed that the colour phases were inherited. However, he provided little evidence on which to base this claim. His family data are summarised in the statement: "White chicks were almost always seen in the nests of white adults, and in the remaining nests both parent birds were not seen ". Presumably, this means that some families with two white parents and a white chick were seen, and also some parent-offspring pairs in which both birds were white.

The genetic basis of colour phase polymorphism has been documented in several undomesticated avian species (e.g. gouldian finch Poephila gouldiae (Southern, 1946); Arctic skua Stercorarius parasiticus (O'Donald and Davis, 1959); the blue-lesser snow goose complex Anser caerulescens (Cooke and Cooch, 1968) and the mute swan Cygnus olor (Munro et al., 1968). The present paper describes studies on the inheritance of plumage phases of Macronectes giganteus and the mortality rates of chicks of the two phenotypes. A comparison of frequencies of the two phases at several breeding localities will be presented elsewhere. 


\section{Materials and MEthods}

In this study, two phenotypes were recognised, white and dark, the latter including all non-white birds. Phenotypes of both chicks and adults are shown in plate I.

Complete family data, consisting of observations of the plumage of both parents and their single chick, were collected from 208 nests in ten colonies on the north-west coast of Macquarie Island in the 1967-68 breeding season.

As only one of the parents was sitting on a nest at a time, each nest was marked with a numbered stake, the incubating bird daubed on the breast with paint, and its phenotype noted; subsequent visits were made to establish the phenotype of the mate. Chicks were all scored in December or early January, i.e. within a month of hatching.

To investigate the possibility of differential chick mortality, the number of chicks of both phenotypes was recorded on two occasions in the 1967-68 breeding season in twenty-eight colonies on the west coast of Macquarie Island. The first count was made in late December, soon after hatching; the second in March, shortly before fledging.

\section{Results}

(i) Family data

Family data are set out in table 1.

TABLE 1

Observed family data for the inheritance of plumage phase in Macronectes giganteus

\begin{tabular}{lrrr} 
& \multicolumn{2}{c}{ Chick phenotypes } & $\begin{array}{c}\text { No. of } \\
\text { chicks }\end{array}$ \\
\cline { 2 - 3 } Type of mating & Dark & White & 174 \\
Dark $\times$ Dark & 172 & 2 & 31 \\
Dark $\times$ White & 17 & 14 & 3 \\
White $\times$ White & 1 & 2 & 208
\end{tabular}

The two hypotheses examined are that plumage phase is controlled by two autosomal allelic genes with, firstly, dark phase dominant to white phase (model I), and secondly, white phase dominant to dark phase (model II). Model I predicts that white $x$ white matings will not give rise to any dark offspring. One such offspring was observed. Similarly, model II predicts that dark $\times$ dark matings will not give rise to any white offspring. In this case, two such offspring were observed. Thus, using these two simple tests, both models must be discarded. However, it is possible to test model I with the omission of the single white $\times$ white mating which gave rise to a dark chick, and model II with the omission of the two dark $\times$ dark matings which gave rise to white chicks.

The expected distribution of progeny on the hypothesis that the inheritance of the two phenotypes is controlled by two autosomal allelic genes is set out in table 4 of $\mathrm{Li}$ (1955). These expectations are derived on the assumption that the family data are collected from a large, random-mating population, and also that there is the same number of offspring per pair. 
Estimates of gene frequency are now obtained from the sample of parents (again assuming a large, random-mating population), and the two models tested with the family data adjusted as indicated.

(a) Model I: dark phase is dominant to white phase

The estimate of the frequency for the recessive allele is:

$$
\sqrt{\frac{35}{414}}=0.291 \text {. }
$$

The expected numbers of progeny from each type of mating on this model are shown in table 2, together with the adjusted observations.

TABLE 2

Observed $(O)$ and expecled $(E)$ numbers of progeny from each type of mating on the hypothesis that plumage phase is controlled by two autosomal allelic genes with dark phase dominant to white (Model I)

\begin{tabular}{|c|c|c|c|c|c|c|c|}
\hline \multirow[b]{3}{*}{ Type of mating } & \multicolumn{4}{|c|}{ Chick phenotypes } & \multirow{3}{*}{$\begin{array}{l}\text { No. of } \\
\text { chicks }\end{array}$} & \multirow[b]{3}{*}{$x_{1}^{2}$} & \multirow[b]{3}{*}{ Probability } \\
\hline & \multicolumn{2}{|c|}{$\underbrace{\text { Dark }}$} & \multicolumn{2}{|c|}{ White } & & & \\
\hline & o & $\mathbf{E}$ & 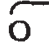 & $\mathrm{E}$ & & & \\
\hline $\begin{array}{l}\text { Dark } \times \text { Dark } \\
\text { Dark } \times \text { White }\end{array}$ & $\begin{array}{r}172 \\
17\end{array}$ & $\begin{array}{r}165 \cdot 2 \\
24 \cdot 0\end{array}$ & $\begin{array}{r}2 \\
14\end{array}$ & $\begin{array}{l}8 \cdot 8 \\
7 \cdot 0\end{array}$ & $\begin{array}{r}174 \\
31\end{array}$ & $\begin{array}{l}5 \cdot 57 \\
9 \cdot 11\end{array}$ & $\begin{array}{l}0.01<\mathrm{P}<0.02 \\
0.001<\mathrm{P}<0.01\end{array}$ \\
\hline White $\times$ White & $0^{*}$ & 0 & 2 & 2 & 2 & - & \\
\hline
\end{tabular}

* Omitting the single white $x$ white mating which gave a dark chick.

(b) Model II: white phase is dominant to dark phase

The estimate of the frequency for the recessive allele in this case is:

$$
\sqrt{\frac{375}{412}}=0.954 .
$$

The expected numbers of progeny from each type of mating on this model are shown in table 3 , together with the adjusted observations.

TABLE 3

Observed $(O)$ and expected $(E)$ numbers of progeny from each type of mating on the hypothesis that

\begin{tabular}{|c|c|c|c|c|c|c|c|}
\hline \multirow[b]{3}{*}{ Type of mating } & \multicolumn{4}{|c|}{ Ghick phenotypes } & \multirow{3}{*}{$\begin{array}{l}\text { No. of } \\
\text { chicks }\end{array}$} & \multirow[b]{3}{*}{$\chi_{1}^{2}$} & \multirow[b]{3}{*}{ Probability } \\
\hline & \multicolumn{2}{|c|}{$\mathrm{N}^{\text {Dark }}$} & \multicolumn{2}{|c|}{ White } & & & \\
\hline & 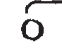 & $\vec{E}$ & $\overparen{O}$ & $\mathrm{E}$ & & & \\
\hline $\begin{array}{l}\text { Dark } \times \text { Dark } \\
\text { Dark } \times \text { White }\end{array}$ & $\begin{array}{r}172 \\
17\end{array}$ & $\begin{array}{l}172 \\
15 \cdot 1\end{array}$ & $0^{*}$ & 0 & 172 & - & $\overline{0.5}$ \\
\hline $\begin{array}{l}\text { Dark } \times \text { White } \\
\text { White } \times \text { White }\end{array}$ & $\begin{array}{r}17 \\
1\end{array}$ & $\begin{array}{r}15 \cdot 1 \\
0.7\end{array}$ & $\begin{array}{r}14 \\
2\end{array}$ & $\begin{array}{r}15 \cdot 9 \\
2 \cdot 3\end{array}$ & $\begin{array}{r}31 \\
3\end{array}$ & $\begin{array}{l}0.45 \\
-\end{array}$ & $\begin{array}{l}0.5 \\
1.0+\end{array}$ \\
\hline
\end{tabular}
plumage phase is controlled by two autosomal allelic genes with white phase dominant to dark (Model II)

* Omitting the two dark $x$ dark matings which gave a white chick.

$\dagger$ Probability calculated using the binomial distribution.

(ii) Differential chick mortality

The numbers of chicks of each phenotype recorded in twenty-eight colonies at Macquarie Island in both December and March of the 1967-68 breeding season are set out in table 4 . The colonies are homogeneous with 
respect to the frequency of white phase chicks, both for the December count $\left(\chi_{8}^{2}=12 \cdot 71,0 \cdot 10<\mathrm{P}<0 \cdot 20\right)$, and for the March count $\left(\chi_{8}^{2}=9 \cdot 42\right.$, $0 \cdot 20<\mathrm{P}<0.30)$. For both homogeneity tests, several colonies were grouped together to ensure that all expectations were greater than five. Only adjacent colonies were grouped.

TABLe 4

Chicks of each phenotype in colonies on Macquarie Island at hatching (December) and fledging (March) in the 1967-68 breeding season

\begin{tabular}{|c|c|c|c|c|c|c|}
\hline \multirow[b]{3}{*}{ Colony } & \multicolumn{3}{|c|}{ Hatching } & \multicolumn{3}{|c|}{ Fledging } \\
\hline & \multicolumn{2}{|c|}{ Phenotype } & \multirow[b]{2}{*}{$\Sigma$} & \multicolumn{2}{|c|}{ Phenotype } & \multirow[b]{2}{*}{$\Sigma$} \\
\hline & Dark & White & & Dark & White & \\
\hline 1 & 88 & 9 & 97 & 75 & 9 & 84 \\
\hline 2 & 15 & 2 & 17 & 14 & 2 & 16 \\
\hline 3 & 8 & 1 & 9 & 8 & 1 & 9 \\
\hline 4 & 15 & 0 & 15 & 13 & 0 & 13 \\
\hline 6 & 6 & 2 & 8 & 4 & 1 & 5 \\
\hline 7 & 10 & 0 & 10 & 6 & 0 & 6 \\
\hline 8 & 19 & 2 & 21 & 14 & 2 & 16 \\
\hline 9 & 8 & 1 & 9 & 6 & 1 & 7 \\
\hline 10 & 41 & 4 & 45 & 40 & 3 & 43 \\
\hline 11 & 58 & 1 & 59 & 57 & 1 & 58 \\
\hline 12 & 26 & 1 & 27 & 20 & 1 & 21 \\
\hline 13 & 23 & 1 & 24 & 23 & 1 & 24 \\
\hline 14 & 34 & 2 & 36 & 34 & 2 & 36 \\
\hline 15 & 9 & 0 & 9 & 9 & 0 & 9 \\
\hline 16 & 12 & 1 & 13 & 11 & 1 & 12 \\
\hline 17 & 23 & 2 & 25 & 23 & 2 & 25 \\
\hline 18 & 19 & 0 & 19 & 19 & 0 & 19 \\
\hline 19 & 8 & 0 & 8 & 8 & 0 & 8 \\
\hline 20 & 24 & 0 & 24 & 22 & 0 & 22 \\
\hline 21 & 27 & 2 & 29 & 27 & 2 & 29 \\
\hline 22 & 38 & 2 & 40 & 34 & 2 & 36 \\
\hline 23 & 30 & 1 & 31 & 16 & 0 & 16 \\
\hline 24 & 68 & 4 & 72 & 61 & 4 & 65 \\
\hline 25 & 9 & 3 & 12 & 4 & 2 & 6 \\
\hline 26 & 29 & 5 & 34 & 27 & 5 & 32 \\
\hline 27 & 34 & 3 & 37 & 20 & 0 & 20 \\
\hline 28 & 117 & 6 & 123 & 100 & 5 & 105 \\
\hline 29 & 76 & 8 & 84 & 63 & 8 & 71 \\
\hline Total & 874 & 63 & 937 & 758 & 55 & 813 \\
\hline
\end{tabular}

Of 874 dark chicks in these colonies, 116 died between hatching and fledging, giving a mortality rate of 0.133 . Of sixty-three white chicks, eight died, giving a mortality rate of $0 \cdot 127$. These mortality rates are not significantly different $\left(\chi_{1}^{2}=0.0012,0.90<\mathrm{P}<0.95\right)$.

As a further test of differential mortality of the two phenotypes, phenotypic frequencies can be compared in a group of chicks and their parents. For the family data in table 1 , the phenotypic frequencies in these two groups are not significantly different $\left(\chi_{1}^{2}=0.01,0.90<P<0.95\right)$. If it is assumed that parental infidelity or fostering is the cause of the two dark $\times$ dark matings which gave rise to white offspring, the family data should be considered with these families omitted. The phenotypic frequencies are still 
Plate I
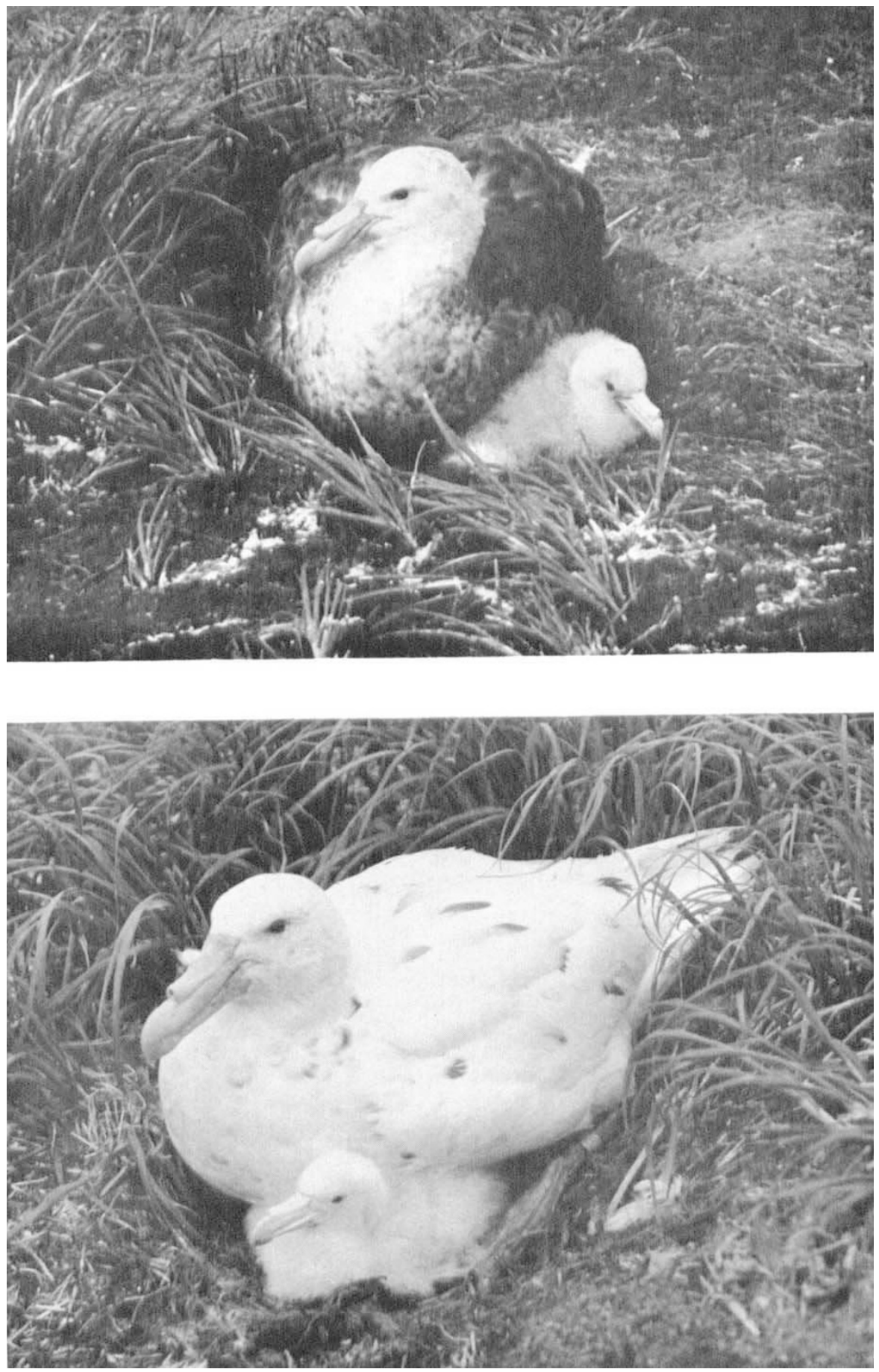

Plumage phase phenotypes of the southern giant petrel Macronectes giganteus

Above: A dark adult with a dark chick.

Below: A white adult with a white chick. 
not significantly different $\left(\chi_{1}^{2}=0.26,0.50<P<0.70\right)$. Thus, the data are consistent with there being no differential selection on the two phenotypes during the chick stage.

\section{Discussion}

The family data (with the omission of the two dark $\times$ dark matings which gave rise to white chicks) are in agreement with the hypothesis that plumage phase is controlled by two autosomal allelic genes, with white phase dominant to dark. On the other hand, the data (with the omission of a single family) are not in agreement with the alternative hypothesis that dark phase is dominant to white. The only family data reported previous to this study (Ardley, 1936) are in accord with both hypothesis.

The anomaly of the two dark chicks which resulted from white $\times$ white matings may possibly be explained by the action of modifying genes, or by infidelity or fostering on the part of one of the presumed parents. Some misclassification of parents is not unexpected among wild populations. The method of collecting family data used in this study would not enable such misclassifications to be detected, unless three adults were actually seen visiting a single nest, and then only if the first two had been daubed with paint and the third, unmarked, bird happened to be present on a subsequent inspection. On the hypothesis that white phase is dominant to dark, misclassification can only be detected among dark $\times$ dark matings. The observed rate is thus $1 \cdot 1$ per cent.

If the inheritance of a trait is controlled by two or more pairs of " duplicate "genes, the expected distribution of progeny is the same as when the inheritance is controlled by a single pair of genes. Theoretically, these cases can be distinguished by considering the segregation ratios in dominant $x$ dominant and dominant $\times$ recessive matings (Li, 1953). However, because of the small sibship size in giant petrels, this would not be possible.

The expectations are quite different if a pair of "complementary" genes (where one phenotype requires the presence of both dominant genes) controls the inheritance of the trait. The most notable difference is that a recessive $\times$ recessive mating can produce offspring of the dominant phenotype. In fact, two such families (if white phase is dominant) or a single family (if dark phase is dominant) was observed. However, the possibility that a pair of "complementary" genes is responsible for the inheritance of plumage phase has not been considered further, as it is not possible to estimate frequencies for the individual genes from field data, and consequently expectations cannot be derived, and so the model cannot be tested.

The expected distribution of progeny on the hypothesis that the inheritance of the two phenotypes is controlled by two autosomal allelic genes is based on two assumptions. The first assumption, that the population is large, is quite justified, as Warham (1962) reported that 2870 chicks hatched at Macquarie Island in 1960. The second assumption is that the population is a random mating one. This can be tested using the numbers of each type of mating from the family data which are presented in table $1\left(\chi_{1}^{2}=1 \cdot 34\right.$, $0.20<\mathrm{P}<0.30$ ). However, the smallest expectation, that for the white $x$ white mating, is only $1 \cdot 36$. Therefore the calculated value of $\chi_{1}^{2}$ will be greater than the true value, and the associated probability is an underestimate. Hence the observed mating frequencies are judged not to differ significantly from random mating frequencies. 


\section{Summary}

1. Two plumage phases of the southern giant petrel Macronectes giganteus were recognised: white and dark.

2. Family data, consisting of observations on 208 single-chick families, were in agreement with the hypothesis that the dimorphism is controlled by two autosomal allelic genes with white phase dominant to dark.

3. Mating frequencies did not differ significantly from those expected with random mating.

4. No evidence was found for differential chick mortality.

Acknowledgments.-The author thanks Dr R. Carrick and Dr M. J. Mayo for helpful discussions, Professor J. H. Bennett for criticising the manuscript, and Mr S. R. Harris for preparing the plate.

Field work was undertaken while the author was a member of Australian National Antarctic Research Expeditions at Macquarie Island, 1967-68. Mr W. J. Merilees assisted with the collection of family data.

\section{REFERENCES}

ARDLEY, R. A. B. 1936. The birds of the South Orkneys. Discovery Rep., 12, 349-376.

CARRICK, R., AND INGHAM, SUSAN E. 1967. Antarctic sea-birds as subjects for ecological research. Proc. Symposium on Pacific-Antarctic Sciences, Tokyo, 1966. JARE Sci. Rep., Spec. Issue No. 1, pp. 151-184. Department of Polar Research, Tokyo.

COOKE, F., AND соOCH, F. G. 1968. The genetics of polymorphism in the goose Anser caerulescens. Evolution, 22, 289-300.

falla, R. A. 1937. Birds. British, Australian, New Zealand Antarctic Research Expedition 1929-31 Rep. Ser. B, 2, 288 pp.

LI, c. C. 1953. Some general properties of recessive inheritance. Am. 7. hum. Genet., 5, 269-279.

LI, C. C. 1955. Population Genetics. University of Chicago Press, Chicago.

MUNRo, R. E., SMrTH, L. T., AND KUPA, J. J. 1968. The genetic basis of color differences in the mute swan (Cygnus olor). Auk, 85, 504-505.

MURPHY, R. c. 1936. Oceanic Birds of South America. American Museum of Natural History, New York.

o'Donald, P., AND DAvis, P. E. 1959. The genetics of the colour phases of the Arctic skua. Heredity, 13, 481-486.

southern, H. N. 1946. Polymorphism in Poephila gouldiae Gould. 7. Genet., 47, 51-57.

WARHAM, J. 1962. The biology of the giant petrel Macronectes giganteus. Auk, 79, 139-160.

wilson, E. A. 1907. Aves. National Antartic Expedition 1901-1904. Natural History: Zoology, 2, 118 pp. 